\title{
Gullian - Barre Syndrome Variant with Unilateral Facial Weakness
}

\author{
Bharat Parmar*, Danu Mori, Ruhi Hathidara and Ashmita Patel \\ B.J. Medical College, India
}

Submission: October 20, 2016; Published: December 13, 2016

*Corresponding author: Bharat Parmar, Associate professor of pediatrics, B.J. Medical College, Civil hospital Ahmedabad, Gujarat, 380016, India, Tel: 9825613362; Email: bjpdr@hotmail.com

\begin{abstract}
It is a postinfectious polyneuropathy due to alteration of protein component of myelin ( $\mathrm{p} 2$ neurotogenic peptide) leading to demyelination because of autoimmune mechanism. Neurological manifestation begins after 2 to 4 weeks of viral or bacterial infection. Clinical expression includes an acute onset symmetrical ascending weakness (both proximal \& distal) with unilateral facial weakness and respiratory weakness and autonomic dysfunction. The diagnosis depends on clinical picture, electrophysiological findings and CSF examination. Immunotherapy is the main stay of treatment. IVIG \& Plasmaphrersis done within 2 to 4 weeks of symptoms onset is recommended. Treatment is warranted in non ambulatory patient (Modified Hughes GBS disability scale). The patient who hav not responded to initial IVIG treatment may benefit from second course of IVIG. General supportive care includes cardiorespiratory care, physiotherapy, nutritional management, management of neuropathic pain, bladder-bowel care and prevention of deep vein thrombosis.

Keywords: Acute inflammatory demelinating polyradiculoneuropathy (AIDP); Acute motor axonal neuropathy (AMAN); Acute flaccid paralysis; Clinical neurophysiology; Immunotherapy

Abbreviations: AIDP: Acute Inflammatory Demelinating Polyradiculoneuropathy; AMAN: Acute Motor Axonal Neuropathy; NCS: Nerve Conduction Study; IVIg: Intravenous Immunoglobulin
\end{abstract}

\section{Introduction}

Gullian - Barre syndrome is also known as acute inflammatory demyelating polyradiculoneuropathy (AIDP), acute motor axonal neuropathy (AMAN). AIDP is the predominant subtype in North America \& Europe while AMAN is commonly reported subtype in Asia including India \& Central \& South America. About $65 \%$ of children report preceding upper respiratory tract $\&$ gastrointestinal tract infection. Immunopathogenesis involve molecular mimicry \& formation of cross reacting antiganglioside antibodies. The GBS has several variants depending upon distribution of motor, sensory, cranial, autonomic or cebellar involvement variant, among them AIDP is the most common [1]

\section{Discussion}

\section{Clinical expression}

- $\quad$ Muscle pain, difficulty while walking or refusals to walk are often the first presenting symptoms (50\%)

- Distal limb weakness which ascending \& symmetrical (20\%) Areflexia.

- $\quad$ Respiratory muscle weakness \& facial weakness (20\%)
- Sensory symptoms including painful parathesia, backache \& meningismus (50\%-80\%)

- Transient bladder involvement can occur in few children.

- $\quad$ Approximately 25\% develop respiratory insufficiency requiring artificial ventilation \& $75 \%$ have autonomic dysfunction. The course is monophasic in most of the children. $80 \%$ reach maximum severity within 2 weeks \& $97 \%$ in 4 weeks. This phase is followed by a relatively static 'plateau phase' ranging from 2 days to 6 months before recovery begins [1].

\section{Diagnosis}

The diagnosis of GBS is clinical \& is supported by a few investigations. Characteristic CSF finding are of AlbuminoCytological dissociation i.e. a combination of elevated CSF protein \& normal cell count. Nerve conduction studies help in diagnosis of different sub types of GBS. In early phase of GBS motor \& sesory nerve conduction study (NCS) is normal. In such situation diagnosis supported by prolonged F waves latencies. NCS abnormalities 
tend to peak by 2 weeks of illness. Children with GBS should be managed in PICU during initial phase (Table 1) [2,3].

Table 1: Common differential diagnosis of Gullian - Barre syndrome [2].

\begin{tabular}{|c|c|c|c|}
\hline $\begin{array}{c}\text { Muscle } \\
\text { Disorders }\end{array}$ & $\begin{array}{c}\text { Neuromuscular } \\
\text { Junction } \\
\text { Disorders }\end{array}$ & Neuropathies & $\begin{array}{c}\text { Central } \\
\text { Nervous } \\
\text { System } \\
\text { Disorders }\end{array}$ \\
\hline $\begin{array}{c}\text { Inflammatory } \\
\text { myopathy }\end{array}$ & Mysthenia gravis & $\begin{array}{c}\text { Diphtheritic } \\
\text { neuropathy }\end{array}$ & $\begin{array}{c}\text { Acute } \\
\text { myelopathy }\end{array}$ \\
\hline $\begin{array}{c}\text { Periodic } \\
\text { paralysis }\end{array}$ & Botulism & Porphyria & Poliomyelitis \\
\hline hypokalemia & $\begin{array}{c}\text { Eaton-lambert } \\
\text { syndrome }\end{array}$ & $\begin{array}{c}\text { Traumatic } \\
\text { neuritis }\end{array}$ & $\begin{array}{c}\text { Brainsem } \\
\text { stroke }\end{array}$ \\
\hline infection & & $\begin{array}{c}\text { Vaculitis } \\
\text { neuropathy }\end{array}$ & $\begin{array}{c}\text { Brainstem } \\
\text { encephalitis }\end{array}$ \\
\hline
\end{tabular}

\section{Clinical neurophysiology}

Earliest abnormalities is a drop in the amplitude of the evoked muscle action potential \& conduction blocks. Marked slowing of nerve conduction can be recorded in about $50 \%$ patients. Reduced compound motor unit potential amplitude is the most frequent finding. Absence or prolongation of $\mathrm{F}$ wave is common. Proximal blocks can be detected by measuring $\mathrm{F}$ wave. Conduction studies improve slowly over a period of several months. Spontaneous fibrillation may detected on electromyography during recovery phase after 2 or 3 weeks [1].

\section{Pathogenesis}

AIDP is multifocal noninfective inflammatory process causing demyelinaton or axonal degeneration of peripheral nerves. ADIP is generally due to T cell mediated immune myelin damage. Increased incidence of several axonal degeneration in GBS following $C$. jejuni infection is known with more severe involvement. The mechanism of axonal damage is different molecular mimicry due to shared epitopes with gangliosides [1] (Figure 1).

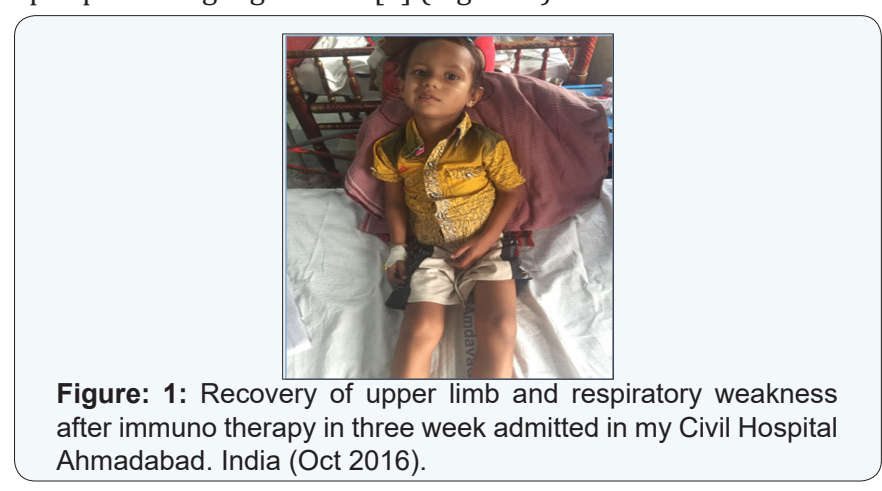

\section{Prognosis}

Recovery is common \& often complete in the majority.Mortality is now $\leq 5 \%$. Most of the death in childhood are due to preventable respiratory complication. Acute axonal neuropathy, with good pgognosis.Acute axonal and sensory axonal neuropathy generally causes poor prognosis. Miller Fisher variant in which cerebellar signs, cranial nerves are involved also has a poor prognosis. The disabilities included foot drop, pes cavus and postural tremor \& persisting weakness of the hands [1].

\section{Treatment}

Supportive symptomatic treatment is the mainstay of therapy in the majority. The child should be closely observed in hospital, objective assessment of respiratory function, regular measurement of vital capacity is performed. Ventilatory support should be considered if there is evidence of respiratory insuffiency $[3,4]$.

- Dysphagia if present necessitates nasogastric feeding.

- $\quad$ Chest and limb physiotherapy should be initiated early and carried out carefully. Bladder and bowel function should be attended to.

- Plasmapheresis has been shown to be effective in decreasing severity and shortening the non ambulatory phase. No significant complication ensue fron well conducted plasmapheresis. Several paediatric studies support the results.

- Intravenous immunoglobulin (IVIg) is atleast as effective as Plasma exchange. IVIg is now become the preferred treatment due to ease of administration. Dose of IVIg $0.4 \mathrm{~g} /$ $\mathrm{kg}$ body weight daily given on five successive days or two successive doses of $1 \mathrm{~g} / \mathrm{kg}$ may be given active treatment of impending/ respiratory failure is imperative. Indication of immunotherapy includes a hughes GBS disabilities scale $\geq 3$ or when patient is unable to walk unaided for 10 meters [5-7].

\section{Conclusion}

Acute flaccid paralysis in children is a medical emergency. AFP is a clinical syndrome with array of differential diagnosis. The common causes of AFP are Gullian - Barre syndrome, Anterior horn cell myelitis and Acute transverse myelitis. Rapid evolution of the weakness can lead to respiratory failure. Hence a child with AEP Should be managed in PICU in the initial few days. Immunotherapy is a main stay treatment.

\section{References}

1. Veena Kalra (2007) Parth's Fundamentals of Paediatrics (1 $1^{\text {st }}$ edn). Gullian Barre syndrome. Jaypee Brothers Medical Publishers (P) Ltd, New Delhi, India, pp. 216-218.

2. Singhi SC, Sankhyan N, Shah R, Singhi P (2012) Approach to a child with acute flaccid paralysis. Indian J Pediatr 79(10): 1351-1357.

3. van den Berg B, Walgaard C, Drenthen J, Fokke C, Jacobs B, et al. (2014) Guillain-Barré syndrome: pathogenesis, diagnosis, treatment and prognosis. Nat Rev Neurol 10(8): 469-482.

4. Sheffali Gulati (2013) IAP Text book of Paediatrics, (vol 2) (5 $5^{\text {th }}$ edn). Gullian Barre Syndrome. IAP National Publication, Gwalior, India, pp. 381-390.

5. Kuwabara S, Yuki N (2013) Axonal Guillain-Barré syndrome: concepts and controversies. Lancet Neurol 12(12): 1180-1188. 
6. Hughes RA, Swan AV, Raphaël JC, Annane D, van Koningsveld R, et al. (2007) Immunotherapy for Guillain-Barré syndrome: a systematic review. Brain 130(9): 2245-2257.
7. Mehharban Singh (2013) A Manual of Essential pediatrics (2 ${ }^{\text {nd }}$ edn). Gullian Barre Syndrome. Thieme Medical and Scientific Publisher Private Ltd, New Delhi, India, pp. 458-459.

Your next submission with JuniperPublishers
will reach you the below assets
- Quality Editorial service
- Swift Peer Review
- Reprints availability
- E-prints Service
- Manuscript Podcast for convenient understanding
- Global attainment for your research
- Manuscript accessibility in different formats
( Pdf, E-pub, Full Text, Audio)
- Unceasing customer service
Track the below URL for one-step submission
http://juniperpublishers.com/online-submission.php

